\title{
Opportunities for Optimizing the Activities of the Investigator and Expert to Improve the Efficiency of the Investigation of Traffic Accidents
}

\author{
Tachir I. Saifutdinov, Amanai T. Akmatova, \\ Egemberdi S. Toktorov and Altinbek E. Toktorov* \\ Osh State Law Institute \\ Osh, Kyrgyz Republic
}

Received 11.07.2020, received in revised form 15.08.2021, accepted 14.09.2021

\begin{abstract}
The subject of the study is to improve the interaction between the activities of participants in the investigation of road traffic offences. From the materials of criminal cases, it is clear that quite often the role and place of the forensic examination is unreasonably diminished by the investigator. It happens due to the fact that a large part of the physical evidence collected at the crime scene during the initial inspection of the scene of the incident and containing the necessary amount of investigatively significant information, falls out of the general picture that forms the content of the investigative situation. The most effective interaction of the investigator with the expert is realized only when it is organized from the very beginning of the investigation of the crime event, and hereby covers all stages of the investigation, from the examination of the crime scene, the appointment of the examination, the process of examination, conclusions, and end results of expert research. Gathering evidence and clarifying all the circumstances that contribute to the commission of the crime seems to be the basis for solving practical problems that confront the investigator upon arrival at the scene of an accident. For the full implementation of these tasks, the investigator resorts to the practical assistance of an expert, a specialist who has methods for solving the questions posed to them, the practical possibilities accumulated in the complex of technical and forensic, as well as theoretical support for the production of examinations. To implement the tasks set for the investigator to investigate accidents, the investigator simply needs to assress an expert for competent answers. In turn, the expert is authorized to take expert initiative in the course of the investigation, within the limits of his expert authority, to identify, evaluate and establish the circumstances indicated by the investigator in the case under investigation. Empirical and theoretical research methods, a comprehensive analysis, and other methods of scientific knowledge were used in the process of study. The results of the study made it possible to formulate a set of recommendations aimed at improving the regulatory framework governing the interaction of the investigator and expert.
\end{abstract}

(C) Siberian Federal University. All rights reserved

* Corresponding author E-mail address: quelle-osh@mail.ru, oshgui-nauka@mail.ru ORCID: 0000-0002-2431-2936 (Saifutdinov); 0000-0002-2791-4238(Akmatova); 0000-0003-1881-5745 (E. Toktorov); 00000003-3947-1080 (A. Toktorov) 
Keywords: investigation team, investigator, interaction, expertise, forensic scientist, professionalism, work, competence, evidence, crime, court.

Researh area: criminal trial, forensics; operational search activities.

Citation: Tachir I. Saifutdinov, Amanai T. Akmatova, Egemberdi S. Toktorov, Altinbek E. Toktorov (2021). Opportunities for optimizing the activities of the investigator and expert to improve the efficiency of the investigation of traffic accidents. J. Sib. Fed. Univ. Humanit. soc. sci., 14(11), 1710-1719. DOI: $10.17516 / 1997-1370-0851$

\title{
Возможности оптимизации деятельности следователя и эксперта-специалиста по улучшению эффективности расследования дорожно-транспортных происшествий
}

\author{
Т.И. Сайфутдинов, А.Т. Акматова, \\ Э.С. Токторов, А.Э. Токторов \\ Оиский государственный юридический институт \\ Кыргызская Республика, Ош
}

\begin{abstract}
Аннотация. Предметом исследования является улучшение взаимодействия деятельности участников процесса при расследовании дорожно-транспортных преступлений. Из материалов уголовных дел видно, что достаточно часто роль и место судебной экспертизы необоснованно принижаются следователем. Именно из-за этого достаточно большая часть собранных на месте события преступления вещественных доказательств при производстве первоначального осмотра места происшествия и содержащих в себе необходимый объем следственно значимой информации, выпадает из общей картины, формирующей содержание следственной ситуации. Наиболее эффективное взаимодействие следователя с экспертом реализуется лишь тогда, когда оно организовано с самого начала расследования события преступления, при этом охватывает все этапы производства следственных действий, начиная с осмотра места события преступления, назначения производства экспертизы, самого процесса производства экспертизы, заключения, выводов и конечных результатов экспертного исследования. Собирание доказательств и выяснение всех обстоятельств, способствующих совершению преступления, представляется основой решения практических задач, встающих перед следователем по прибытии на место ДТП. Для полноценной реализации этих задач следователь прибегает к практической помощи эксперта, специалиста, имеющих в содержании способы решения поставленных перед ними вопросов, практические возможности, аккумулированные в комплексе технико-криминалистического и теоретического обеспечения производства экспертиз. Для реализации поставленных перед следователем задач по расследованию ДТП ему просто необходимо обращаться за компетентными ответами к эксперту. В свою очередь, эксперт полномочен проявлять экспертную инициативу в ходе производства расследования в пределах своих экспертных полномочий для выявления оценки и установления обозначенных следователем обстоятельств по расследуемому
\end{abstract}


делу. В процессе написания работы были использованы методы эмпирического и теоретического исследования, комплексного анализа и другие методы научного познания. Результаты исследования позволили сформулировать комплекс рекомендаций, направленных на совершенствование и улучшение нормативноправовой базы, регулирующей взаимодействие следователя и эксперта.

Ключевые слова: следственная группа, следователь, взаимодействие, экспертиза, криминалист, профессионализм, работа, компетентность, доказательство, преступление, суд.

Научная специальность: 12.00 .09 - уголовный процесс.

\section{Introduction}

Continuous interaction, coordinated by common goals and objectives between the subjects conducting the investigation and experts, is determined by the fact that the investigator is not able to individually collect, study and analyze evidence due to his lack of relevant knowledge and skills, as a result, independently solve the crime without involving specialists with relevant competence.

In accordance with article 158, part 3 of the Criminal Procedure Code of the Kyrgyz Republic where the norm «that the use of technical means and scientifically sound methods of detecting, fixing and seizing traces of crime and material evidence is mandatory» is indicated (The Criminal Procedure Code of the Kyrgyz Republic dated 02.02.2017 No. 20 (as amended by the Law of the Kyrgyz Republic dated 15.05. 2019 No. 62), implies the mandatory presence of an expert, including a specialist, during the investigation.

At the same time, article 60 of the Criminal Procedure Code of the Kyrgyz Republic presupposes only optional possibility of specialist participation in the production of investigative actions. At the same time, neither an expert nor a specialist have the ability to take competent initiatives on issues related to the crime event, but not brought before them by the investigating authority.

At the same time, an expert, according to part 3, part 9, article 60 (The Criminal Procedure Code of the Kyrgyz Republic of 02.02.2017 No. 20 (as amended by the Law of the Kyrgyz Republic of 05.15.2019 No. 62) can be prosecuted for a knowingly false conclusion, unlike a specialist who, in essence, will be pun- ished only with disciplinary action for the same actions, which intrinsically distinguishes a specialist from the point of view of independence in choosing and making «any» decision from the prosecution and the defense.

Hence the statement of the next question, how necessary is the expert's conclusion as a procedural component. And if it is not necessary, then what is his procedural status as an evidence. In addition to the questions posed, there are other issues related to the organization of joint actions of the investigator and expert in the course of joint actions to verify databases and various forensic and expert records in the investigation of crimes related to traffic accidents.

\section{Statement of the problem}

Today it is necessary to develop joint actions of the investigator, expert and specialist, aimed at optimizing the investigation of crimes related to traffic accidents.

Analyzing the characteristic components of the concept of «interaction», the author came to the definition of its essence expressed in the author content.

«Interaction is a special organizational form of action defined by the law. It is related to interdepartmental normative documents, implemented by independent entities, on the basis of unified leadership from the subject directing the investigation and using the competencies of an expert and specialist to obtain an opinion during the investigation of a crime, including providing them with other non-procedural assistance.»

As a rule, the limits of interaction between an investigator, an expert and a specialist are 
limited by the need to apply special knowledge, skills, and technologies (specific knowledge). In connection with this, the author formulated their content and the boundaries of professional competence:

1) Investigator's competencies consist of a set of professional knowledge, skills and abilities of the right to apply, in the framework of training acquired in special educational institutions, practical experience sufficient to conducting an investigation.

2) The competence of an expert and specialist is the availability of sufficient theoretical knowledge and practical skills in applied and related branches of scientific knowledge, during special vocational training in educational institutions, empirical and practical experience sufficient to conducting competent research and assisting in the investigation.

\section{Discussion}

In the course of scientific research, the author have developed a number of proposals designed to optimize the quality and effectiveness of the interaction of the investigator, expert and specialist:

1) To unify the legal base of expert activity at the interdepartmental level.

2) To develop measures and their legal basis for the implementation of the possibility of constant monitoring by the heads of expert units over the practical activities of experts within the framework of carrying out examinations during a crime investigation.

3) The general initiative preventive activity of the investigator, expert, and specialist (by the method, purpose, nature, and place of implementation).

4) The solution of problematic issues of the exchange of current investigative information on the practical application of the results of expert and specialist's conclusions.

5) Development of program recommendations and guidance on typical situations related to accidents.

Hence, there is a need to apply special scientific knowledge and realize the capabilities of the forensic technology, which skills an expert and a specialist possess; the investigator has a practical need for organizing com- prehensive interaction. Being in a neutral legal and administrative interdependence from each other and guided by their normative legal acts in the organization of their activities within the framework of competent authority, they are, at the same time, united within the boundaries of one department or structures of law enforcement agencies (Demidova, 2008).

Therefore, it is logical that the head of the structural unit represented by the head of the investigative apparatus and the head of the forensic and expert unit implement joint organizational measures aimed at organizing comprehensive interaction, both departmental and interdepartmental (Averyanova, 2006).

\section{Theoretical framework}

In the process of scientific research of the presented topic, the authors faced the problem of theoretical definition of a number of contents and their concepts, such as «special knowledge of the investigator», «special knowledge of the expert and specialist.»

As a result, the authors formulated a definition of the following content: «the special knowledge of the investigator is theoretical, practical and legal knowledge obtained in the framework of special professional training.» Influencing the formation of the entire spectrum of professional competence of an investigator and implemented by him in the process of disclosing and investigating criminal cases (Beketov, 2004).

«Special knowledge of an expert and a specialist is acquired scientific knowledge, applied theoretical skills and practical skills in various fields of scientific knowledge, branches of law, psychology, art, medicine, crafts, technology. Providing a continuous process of professional activity aimed at the production of various types of forensic examinations designed to ensure the production of crime investigations and crime prevention» (Gorodokin, Tichin, Usmanov, 2007).

In defining the meaningful characteristics of the investigator's interaction with an expert and specialist, the authorsoffer the concept implying the totality of the joint actions they implement, coordinated by place, purpose, conditions and tasks, and designed to create optimal 
conditions for the disclosure and investigation of criminal cases and preventive work (Zhulev, Stepanishchev, 2004).

Based on the foregoing part of the study, the authors classified the most common investigations in practice, the forms of interaction between an investigator and an expert, a specialist, during the investigation of an accident and related crimes:

1) in the form of normative legal regulation - procedural interaction, during the investigation of a criminal case, not procedural, i. e. everyday;

2) in terms of interaction time - temporary, permanent, periodic, situational;

3) according to the principles of organizational activity - organization of work as part of the SOG, involvement in the production of individual investigative actions in the production of special investigative actions, joint analytical work, organizational planning of the investigation;

4) on the initiative of organizing interaction - investigative practice shows that organizational interaction in the investigation of a crime is oversaturated with regulatory legal acts of a discretionary interpretation, both procedural and departmental, with a lack of a clear production algorithm in which contradictory and inadequate content are indicated norms with the lack of targeting performance.

The main regulator governing joint activities in the investigation, for the investigator, expert and specialist is the Criminal Procedure Code. Outside of the investigation for an expert and a specialist, the law «On Forensic Expert Activity» (Law «On Forensic Expert Activity» No. 100 of June 24, 2013, was adopted by the Jogorku Kenesh of the Kyrgyz Republic on May 16) as a guiding document in everyday activities not related to the investigation 2013).

In the new, existing Criminal Procedure Code of the Kyrgyz Republic, for the first time, a clear distinction between participants in the process on the defense side and the prosecution side is made. However, at the same time, the developers of the code assigned neither an expert nor a specialist to either side, thereby determining their place in a separate, specific group.
In other words, considering them as other participants in the criminal procedure, thus indicating the neutrality of these entities, and emphasizing that the expert and specialist are neither prosecution nor defense.

By the new Criminal Procedure Code of the Kyrgyz Republic, which designated the probability of attracting an expert, as a subject who previously got familiar with the materials of the investigation, as a specialist an expert can be appointed from the persons proposed by a process participant» (The Criminal Procedure Code of the Kyrgyz Republic of February 2, 2017, No. 20 (As amended by the Law of the Kyrgyz Republic of May 15, 2019, No. 62, P. 1. Article 59).

Meanwhile, the content of the characteristics of the specialist's competencies in the criminal procedure norms is insufficient and requires specification. In the norms of the Criminal Procedure Code, a list of the specialist's rights is indicated, while there are no duties imposed to him in the framework of a criminal investigation.

The authors believe that the legislator thereby makes a comparative reference regarding the duties of a specialist to the duties of an expert indicated by the Law «On Forensic Expert Activity», but this is not the same at all.

In the procedural rules designated as definitions, the authors did not find clear boundaries of the procedural and non-procedural forms of application of the competencies of a specialist. They do not have a designated procedural status, certificates, petitions, the procedure for appointing consultations and explanations given by a specialist and their further procedural significance, as well as the procedure for their application.

In addition to the regulation listed in the procedural rules, the legal status of the heads of expert services is not lay down; its role and degree of participation are not indicated. In addition, most importantly, responsibility in the production of complex examinations (Zaitseva, 2003).

The current norms of the criminal process govern not all problematic issues that arise during the interrogation of a specialist and his testimony. 
According to the authors, this happens due to the fact that the concept of «expert opinion» is not laid down in the procedural norms. As a result, there is no regulation on its content, volume, and the requirements for the limits and comprehensiveness of expert research. This fact is an internal contradiction of the Criminal Procedure Code, since the expert can give opinions and testimony, while the specialist, being the subject of the criminal process, is limited to testifying during the investigation of the crime. Although the field of application of scientific knowledge and competencies of a specialist is much more informative for the investigation. In connection with the above circumstances, it is clear that the addition of a separate article «Conclusion and Interrogation of a Specialist» of the Criminal Procedure Code into the section, «evidence and evidence» is simply necessary.

As well as replenishment of procedural omissions, articles in the form of the concepts of «expert opinion», «procedural procedure for obtaining a specialist opinion», «presentation of a specialist opinion», «procedure for interrogating a specialist»».

As well as developers, there is expert's responsibility for giving an incorrect or knowingly false testimony (conclusion). The authors believe that the exclusion of these conflicts in the current criminal procedure in relation to competences and the right of authority of a specialist will allow. In many cases that do not require an expert opinion, the expert's conclusion regulated by the procedural rules is enough to do with the expert's conclusion and this qualitatively optimizes both the investigation process itself and the effectiveness of the entire expert's and specialist's activities. In addition to the norms of the criminal process, the Law on Forensic Expertise regulates the activities of experts of state expert institutions.

The Law of the Kyrgyz Republic «On Internal Affairs Bodies of the Kyrgyz Republic») regulates the organizational interaction of the investigator with the staff of forensic units during the investigation of crimes (The Law of the Kyrgyz Republic «On Internal Affairs Bodies of the Kyrgyz Republic» was enacted by the resolution of the Jogorku Kenesh of the Kyrgyz
Republic of January 11, 1994, No. 1361-XII, p.11, Article 9).

The regulatory legal acts of the law enforcement bodies of the Kyrgyz Republic as a whole regulate all organizational and managerial as well as operational and investigative activities in the fight against crime, but in addition to these aspects, organizational and legal relations regulate interaction of the investigator with an expert, an expert on issues related to the investigation of crime and their prevention. Thus, intra-departmental normative documents supplement and continue the regulatory norms of the criminal process in organizational matters of interaction between the investigation and the expert, or specialist. However, in these designated regulatory functions, questions requiring a clearer definition and interpretation remain.

An example is such a non-procedural type of organizational interaction in the framework of an investigation as a «specialist certificate». The specified type of interaction requires legal decoding and determining the position among the sources of evidence along with "conclusion and testimony of an expert» (The Criminal Procedure Code of the Kyrgyz Republic of February 2, 2017, No. 20 (As amended by the Law of the Kyrgyz Republic of May 15, 2019, No. 62, Section 2, Article 82).

This form of interaction is not stipulated by the norms of the criminal process, needs specification from the position of normative acts of law enforcement agencies, supplementing the process of investigation of the crime itself. In addition, the rules governing the organization of interaction for the prevention and prevention of crimes are not regulated.

According to the authors, the existing directions for the implementation of procedural and non-procedural forms of interaction of the investigator, specialist and expert need improvement. The authors in his study attempted to analyze and generalize all possible areas of interaction between the investigator and the staff of forensic departments. In this case, the procedural form of interaction of the investigator with the staff of the forensic departments is established by the criminal procedure legislation. Directions for the implementation of 
this form of interaction are involvement of the staff of forensic departments by the investigator to participate in the conduct of investigative or judicial actions, to give expert opinions and testimonies, as well as to conduct forensic examinations (Ilarionov, 1989).

The study found that a specialist's assistance of in the production of investigative actions is used incompetently or insufficiently. Subsequently, an unqualified inspection extremely negatively affects the obtaining of initial data for forensic examinations and, ultimately, the entire course and results of the investigation (Zhulev, Stepanishchev, 2004).

Non-procedural is the form of interaction of the investigator with the staff of forensic departments, provided for not by the criminal procedure code, but by departmental normative legal acts. Directions for the implementation of this form can be developed by practice, but at the same time, they should not contradict the provisions of regulatory legal acts.

Analysis of the investigation of crimes by the investigating units of the Osh city police department revealed a characteristic pattern in everyday investigative and expert practice, it consists in the fact that, as a rule, investigators mainly address the issues of organizing interaction with an expert or specialist only when organizing and conducting the necessary forensic examinations and practically once during the production of other investigative actions or preventive work.

However, it is indisputable that it is precisely the expert and specialist in the investigation of the road traffic crime events that can most fully and competently assist the investigator in conducting the investigative experiment, various types of interrogations, and checking the evidence at the scene of the crime event. Moreover, the participation of an expert and a specialist is methodologically necessary when providing analysis of the results of investigative actions in road accidents (Krivitsky, Shaporov, 2004).

Analyzing the investigative and expert practice, as well as the opinions expressed by the most competent investigators and experts specializing in the investigation of road traffic crimes, the authors substantiated a number of practical recommendations on the participation of an expert in investigative actions in the investigation of an accident:

1) for the preparation, planning and production of an investigative experiment;

2) at the stage of preparation, planning, verification of evidence at the crime scene;

3 ) in the preparation and organization of interrogation of participants in the crime event;

4) during the collection of the study and analysis of samples of a comparative study.

In the course of the study, the author outlined the most common problems of organizational planning of interaction, in the disclosure and investigation of crime events, which must be resolved in the first place. Among them, the author included:

1) coordination of organizational planning issues related to the individual activities of all group participants;

2) the most comprehensive identification, collection, fixing and analysis of traces of the crime event;

3) analysis and production of a set of preliminary studies based on the results of the collected materials at the scene;

4) determination and coordination of the most optimal tactics for the production of forensic examinations;

5) organization of necessary management measures aimed at planning and implementing the interaction of the investigator with an expert, or specialist to identify all the circumstances of the incident.

An analysis of the investigator's practical activities indicates that, as a rule, questions of the investigator's direct interaction with the expert are limited only to assisting in the technique of forensic research and the preliminary investigation of materials collected at the scene of the incident, while the results of such interaction used only for operational purposes. However, subject to the experience and professional competence of the subjects used as experts, specialists, and the provision of their technical and forensic tools for scientific research, their real capabilities will increase significantly (Komarov, Ganzin, Zhirkov, Klepik, Komarov, 2015).

From the materials of the investigative practice, it is clear that forensic experts and 
other specialists are perceived by an investigator as optional participants in the investigative actions. Unfortunately, in practice there are cases of inefficient management of specialists' activities.

Based on the study, the authors conclude that this situation is unacceptable. To solve this problem, it is necessary to form a permanent investigative operational group that specializes in arriving to the accident scene in each department of the internal affairs bodies. The activities of such a group should be enshrined in departmental regulations. It is known that during inspection of a scene there is a preparation of materials for the conduct and appointment of examinations. However, a number of problems arise here. The incompleteness of the initial data often leads to the need for additional or repeated examinations, which ultimately leads to a violation of the procedural deadlines and well-grounded complaints of victims. The solution to these problems is in fixing the mandatory involvement of a forensic specialist, vehicle technician, and trasologist in order to examine the scene of the incident in cases when serious damage to health or the death of the victim has been caused at the legislative level (Chava, 2007).

In his reasoning, the authors conclude that the interaction between the investigator and the expert, as well as the specialist, has the most effective content in the framework of the investigation, it is formed in the presented areas and has the following content:

1) target determination of the subject of expert activity by investigators, when planning and organizing interaction is based on their professional qualities, professional preparedness, and competence. It is done to establish psychological contact and optimize the effectiveness of joint activities in the investigation of a crime;

2) organization of joint planning and situational interaction of the investigator and the expert. Definition and concretization of individual and joint tasks for each stage of the investigation, as well as the procedure for changing the investigative situation, issues of application and practical use of special technical means;
3) clarification of the tactical features of the beginning of an investigative action, the implementation of which is carried out by each of the parties independently within its competence, but taking into account the general plan;

4) the use of modern scientific and technical means of fixing the results of investigative actions and the process of their production.

The event of the production of the investigative action and its results are described in the protocol in the order of their production, and, if necessary, the specialist helps the investigator to draw up diagrams, tables, drawings, explanatory annexes to the protocol of the investigative action with its remarks and explanations;

5) a general analysis of the results by the investigator and expert, the development of a methodology for correcting errors and shortcomings that have arisen.

\section{Conclusion}

For the subsequent implementation of the proposals, it is necessary:

1) create practical conditions for monitoring the activities of employees by the heads of forensic departments not only at the stage of collecting and investigating evidence of a crime, but also at the stage of introducing practical recommendations aimed at conducting optimal research from the perspective of training, competence and modern techniques proposed by them;

2) development of scientifically sound and significant recommendations for the investigation of preventive measures should be carried out through joint organizational interaction of the investigator with the staff of forensic departments;

3) implementation of a program to develop a unified information database containing a decrypted list of all circumstances, causes, consequences that are significant for investigative and expert preventive activities to prevent traffic accidents and their consequences, as well as containing practical recommendations on the most typical situations based on modern scientific developments and proposals;

4) it is important to implement the exchange process at the investigator-expert level 
with the results of the practical use of preventive recommendations designed to eliminate the problematic issues that arise during the investigation of cases of traffic accidents.

\section{References}

Averyanova, T.V., Statkus, V. (2013). Prakticheskoe rukovodstsvo po proizvodstvu sudebnykh expertiz dlia expertov i spesialistov [Practical Guide on the Production of Forensic Examinations for Experts and Specialists], Iurait, $724 \mathrm{p}$.

Averianova, T.V. (2006). Sudebnaia expertiza. Kurs obchshei teorii [Forensic Examination. General Theory Course], Moscow, $480 \mathrm{p}$.

Baiett, P., Wotts, P. (1983). Rassledovanie dorozhno-transportnkyh proishestvii [Traffic Accident Investigation], Moscow, Transport, $288 \mathrm{p}$.

Beketov, M.IU. (2004). Sledovatel' organov vnutrennikh del i milisiia: vzaimodeistvie pri rassledovanii prestuplenii [Interior Investigator and Police: Interaction in Investigating Presences], Moscow, $96 \mathrm{p}$.

Ganzin, S.V., Chustov, A.V., Komarov. Iu. Ia. (2015). Dorozhnye usloviia i bezopasnos't dvizhenia [Road Conditions and Traffic Safety], Volgograd, $94 \mathrm{p}$.

Gorodokin, V.A., Tichin, D.V., Usmanov, R.A. (2007). Osmotr mesta dorozhno-transportnogo proischestvia [Inspection of the Scene of a Traffic Accident], Cheliabinsk, $78 \mathrm{p}$.

Demidova, T.V. (2010). Vzaimodeistvie slidovatelia s sotrudnikami ekspertno-kriminalisticheskikh podrazdelenii pri rassledovanii dorozhno-transportnykh prestuplenii [Interaction of the Investigator with the Staff of Forensic Departments in the Investigation of Traffic Crimes], Moscow, $232 \mathrm{p}$.

Demidova, T.V. (2008). Problemnye voprosy pravovogo regulirovania vzaimodeistvia sledovatelia s sotrudnikami ekspertno-kriminalisticheskikh podrazdelenii [Problematic Issues of Legal Regulation of the Interaction of the Investigator with the Staff of Forensic Departments], In Vestnik kriminalistiki [Bulletin of Forensics], 4, 89-92.

Zhulev, V.I., Stepanishchev, A.V. (2004). Rassledovanie dorozhno-transportnykh prestuplenii: metodicheskie rekomendatsii [Investigation of Traffic Crimes: Guidelines], Moscow, 190 p.

Zaitseva, E.A. (2003). Pravovoi institut sudebnoi ekspertizy v sovremennykh usloviiakh [The Legal Institute of Forensic Examination in Modern Conditions], Volgograd, $143 \mathrm{p}$.

Zakon O sudebno-ekspertnoi deiatelnosti ot 24.06.2013 № 100, byl priniat Zhogorku Kenechem Kyrgyzskoy Respubliki 16.05.2013 [The Law «On Forensic Science Activities» of June 24, 2013 No. 100 was adopted by the Jogorku Kenesh of the Kyrgyz Republic on May 16, 2013].

Zakon Ob organakh vnutrennikh del Kyrgyzskoi Respubliki vveden v deistvie postanovleniem Zhogorku Kenecha Kyrgyzskoy Respubliki 11.01.1994 N1361-XII) p.11.st.9 [The Law of the Kyrgyz Republic «On Internal Affairs Bodies of the Kyrgyz Republic» was enacted by the resolution of the Jogorku Kenesh of the Kyrgyz Republic of January 11, 1994 No. 1361-XII) p.11.Article 9.)].

Ilarionov, V.A. (1989). Ekspertiza dorozhno-transportnykh proischestvii. Uchebnik dlia vuzov [Examination of Traffic Accidents. Textbook for High Schools], Moscow, $255 \mathrm{p}$.

Komarov, Yu. Ya, Fedotov, V.N. (2006). The Influence of Fixed-Route Taxi on Road Accidents and Air Pollution, Lithuania, In Transport, XXI (1) 34-37.

Komarov, Yu. Ya., Fedotov, V.N. (2006). The Model of Harmful Ejections Dissemination of the Transport Flows Made on the Basis of the Calculation of the Turbulent Diffusion Equation, Lithuania, In Transport, XXI, (3), 213-217.

Komarov, Yu. Ya., Ganzin, S.V., Jirkov, R.A., Klepick, N.K., Komarov, D. Yu. (2015). Ekspertiza dorozhno-transportnykh proischestvii v primerakh $i$ zadachakh [Examination of Traffic Accidents in Examples and Tasks], Volgograd, $292 \mathrm{p}$.

Korukhov, Yu.G. (1988). Transportno-trasologicheskaia ekspertiza po delam o DTP (Diagnosticheskoe issledovanie). Metodicheskoe posobie dlia ekspertov, sledovatelei, sudei/ [Transport and Trasological Examination in Cases of Road Traffic Accidents (Diagnostic Studies). A Toolkit for Experts, Investigators, Judges, All-Russian Research Institute of Forensic Expertise, Moscow, 104 p. 
Krivitsky, A.M., Shaporov, Yu.I. (2004). Ispolzovanie spetsialnykh poznanii v rassledovanii dorozhnotransportnykh proischestvii [The Use of Special Knowledge in the Investigation of Traffic Accidents], Minsk, $128 \mathrm{p}$.

Krylov, I.F., Bastrykin, A.I. (2001). Kriminalistika [Forensics], Moscow, 799 p.

Solokhin, A. (1968). Sudebno-meditsinskaia ekspertiza v sluchaiakh avtomobul'noi travmy [Forensic Medical Examination in Cases of Automobile Injury], Medicine, 237p.

Ugolovno-protssesualnyi kodeks Kyrgyzskoi Respubliki ot 02.02.2017 № 20 (V redaktsii Zakona Kyrgyzskoi Respubliki) [The Criminal Procedure Code of the Kyrgyz Republic of 02.02.2017 No. 20 (As amended by the Law of the Kyrgyz Republic of 05.15.2019 No. 62)].

Chava, I.I. (2007). Sudebnaia avtotekhnicheskaia ekspertiza. Issledovanie obstoiatel'stv DTP. Uchebno-metodicheskoe posobie. [Forensic Automotive Technical Expertise. Investigation of the Circumstances of an Accident. Teaching aid]. Moscow, $98 \mathrm{p}$.

Chelysheva, O.V., Sotnikov, K.I., Kuzbagarova, E.V. (2017). Kriminalistika [Forensics], Moscow, 839 p. 